\title{
Acupuncture Treatment for Facial Nerve Palsy - Is It Effective?
}

\author{
Zogopoulos Panagiotis ${ }^{1 *}$, Gkorgkolis Vasileios ${ }^{2}$, Venetikidis Anastasios ${ }^{1}$, Vretakos Georgios ${ }^{1}$ and $^{\text {Rologis }}$ \\ Dimitrios $^{1}$
}

${ }^{1}$ Department of Neurosurgery, Metropolitan Hospital, Greece

${ }^{2}$ St. Andrews Centre for Plastic Surgery and Burns, Broomfield Hospital, UK

Submission: February 06, 2017; Published: February 14, 2017

*Corresponding author: Zogopoulos Panagiotis, Neurosurgery Department, Metropolitan Hospital, Athens, Greece,

Email: p.zogopoulos@yahoo.com

\begin{abstract}
Acupuncture treatment is under extensive investigation over the last years concerning its therapeutic potential in a wide range of diseases. Significant progress has been made recently in deciphering various mechanisms of action of acupuncture, especially regarding its neuroprotective effects in patients with neuronal injury, such as stroke. We present a mini-review of available experimental and clinical data about the efficacy of acupuncture treatment in patients with facial nerve palsy.
\end{abstract}

\section{Introduction}

Acupuncture has been extensively practiced in China over the last 3000 years, and more recently worldwide, for a wide range of diseases and conditions. Western medical acupuncture refers to the integration of this ancient treatment modality into modern clinical practice. As research in the field of acupuncture has exhibited a rapid progress, especially within the last three decades, many of its effects have been clarified in terms of neuroanatomy, neurophysiology and neurobiology. Acupuncture stimulation has been proven to induce various responses, such as autonomic, neuroendocrine, psychological and behavioral, through the activation of both peripheral and central nervous system. Recently, there have been reports that acupuncture treatment can promote and enhance adult neurogenesis and suggested mechanisms include upregulation of brainderived neurotrophic factor (BDNF), glial cell line-derived neurotrophic factor (GDNF), basic fibroblast growth factor (bFGF) and neuropeptide Y (NPY) [1-5]. Neurogenic properties of acupuncture are currently under extensive investigation, especially regarding its therapeutic potential for cranial nerve palsies, such as those of the facial nerve.

\section{Background}

Neurophysiological investigations have shed light on the mechanisms of acupuncture-mediated recovery of nerve palsies. In particular, such mechanismsinclude regulation of neurotransmitters, neurohormonesand various neuromodulators/neurotrophins. Neurotrophins are a family of growth and survival factors that regulate neuronal development and function $[6,7]$.
Facial nerve palsy is a rather common condition that is clinically manifested with paralysis of the facial-nerve innervated structures. Specifically, there can be unilateral facial weakness, loss of taste sensation, hyperacusis, as well as decreased tear secretion and salivation [8]. There are various causes that can lead to facial nerve palsy, including infection, trauma, tumors and stroke, although other less frequent causes also exist (diabetes mellitus, neurosarcoidosis, Guillain-Barré syndrome and Moebius syndrome) [9]. Bell's palsy (the most common cause of acute facial nerve palsy) is idiopathic and thus, can only be diagnosed by exclusion. However, it has been associated wih viral infections (such as herpes simplex virus). It may last from days to several months and it usually recovers spontaneously, but corticosteroids are often administered to speed up recovery [9].

\section{Experimental \& Clinical Data}

Acupuncture has been shown to regulate glucose metabolism, as well as activate neuronal plasticity in ischemic stroke patients $[10,11]$. Its more potent form, electroacupuncture (EA), has also been found to exert anti-inflammatory actions through downregulation of proinflammatory cytokines TNF- $\alpha$, IL- $1 \beta$ and IL- 6 $[12,13]$.

EA stimulation in experimental animal stroke models resulted in improved neuronal function and induced proliferation and differentiation of neuronal stem cells, as well as inhibition of neuronal apoptosis $[14,15]$. Furthermore, it seems to promote neuronal functional recovery via activation of the retinoic acid 


\section{Open Access Journal of Neurology \& Neurosurgery}

signaling pathway, but also repair neurons under stress undergoing apoptosis via activation of heat-shock proteins [16,17].

In a randomized controlled trial in patients with central facial nerve paralysis after ischemic stroke, acupuncture stimulation resulted in significant clinical improvement, as evaluated with the House-Brackmann facial nerve grading system, Toronto facial grading system and physical function score in facial disability index [18].

In another study of patients with Bell's palsy, acupuncture treatment efficacy was found to be negatively correlated with the severity of facial nerve dysfunction, while the necessary period of treatment was positively correlated with the severity of facial nerve dysfunction [19]. Furthermore, EA exhibited significantly greater therapeutic potential and was associated with a shorter duration of treatment in terms of facial nerve function recovery, compared to manual acupuncture in patients with Bell's palsy [20].

\section{Conclusion}

Acupuncture treatment (and its more potent form electroacupuncture) seems to be an effective and safe adjuvant treatment modality (combined with standard medication) for patients with facial nerve paralysis, such as Bell's palsy. Since there is evidence that facial nerve function recovery can be achieved faster, without any treatment-associated adverse effects, acupuncture should be integrated in the clinical practice of each physician that treats patients with such disorders.

\section{References}

1. Ou YW, Han L, Da CD, Huang YL, Cheng JS (2001) Influence of acupuncture upon expressing levels of basic fibroblast growth factor in rat brain following focal cerebral ischemia- Evaluated by time-resolved fluorescence immunoassay. Neurological Res 23(1): 47-50.

2. Kim EH, Jang MH, Shin MC, Lim BV, Kim HB, et al. (2002) Acupuncture increases cell proliferation and neuropeptide $\mathrm{Y}$ expression in dentate gyrus of streptozotocin-induced diabetic rats. Neuroscience Lett 327(1): 33-36.

3. Dong ZQ Ma F, Xie H, Wang YQ, Wu GC (2005) Changes of expression of glial cell line-derived neurotrophic factor and its receptor in dorsal root ganglions and spinal dorsal horn during electroacupuncture treatment in neuropathic pain rats. Neuroscience Lett 376(2): 143-148.

4. Hwang IK, Chung JY, Yoo DY, Yi SS, Youn HY, et al. (2010) Effects of electroacupuncture at Zusanli and Baihui on brain-derived neurotrophic factor and cyclic AMP response element-binding protein in the hippocampal dentate gyrus. J Vet Med Sci 72(11): 1431-1436.

5. Nam MH, Yin CS, Soh KS, Choi SH (2011) Adult neurogenesis and acupuncture stimulation at ST36. J Acupunct Meridian Stud 4(3): 153158.
6. McAllister AK (2001) Neurotrophins and neuronal differentiation in the central nervous system. Cell Mol Life Sci 58(8): 1054-1060.

7. Poo MM (2001) Neurotrophins as synaptic modulators. Nat Rev Neurosci 2(1): 24-32.

8. Colledge NR, Walker BR, Ralston SH (Eds.), (2010). Davidson's principles and practice of medicine. Illust Robert Britton $\left(21^{\text {st }}\right.$ edn $)$. Edinburgh: Churchill Livingstone/Elsevier, ISBN 978-0-7020-3084-0.

9. Fauci AS, Harrison TR (2008) Harrison's principles of internal medicine (17 ${ }^{\text {th }}$ edn), McGraw-Hill Medical, New York, USA, ISBN 9780-07-147693-5.

10. Huang Y, Tang C, Wang S, Lu Y, Shen W, et al. (2012) Acupuncture regulates the glucose metabolism in cerebral functional regions in chronic stage ischemic stroke patients - A PET-CT cerebral functional imaging study. BMC Neurosci 13: 75.

11. Fang Z, Ning J, Xiong C, Shulin Y (2012) Effects of electroacupuncture at head points on the function of cerebral motor areas in stroke patients: A PET study. Evid Based Complement Alternat Med 2012: 902413.

12. Zogopoulos P, Vretakos G, Rologis D (2015) The role of electroacupuncture in stroke treatment: A systematic review of the literature. Journal of Neuroscience and Behavioral Health 7(6): 40-47.

13.Zogopoulos P, Karavis M, Venetikidis A, Vretakos G, Theocharis S, et al. (2017) Acupuncture-Mediated Activation of the Cholinergic AntiInflammatory Pathway - A Review of the Literature. Open Access Neurol Neurosurg 2(2): 1-3.

14. Tao J, Xue XH, Chen LD, Yang SL, Jiang M, et al. (2010) Electroacupuncture improves neurological deficits and enhances proliferation and differentiation of endogenous nerve stem cells in rats with focal cerebral ischemia. Neurol Res 32(2): 198-204.

15. Kim YR, Kim HN, Ahn SM, Choi YH, Shin HK, et al. (2014) Electroacupuncture Promotes Post-Stroke Functional Recovery via Enhancing Endogenous Neurogenesis in Mouse Focal Cerebral Ischemia. PLoS One 9(2): e90000.

16. Cakmak YO (2009) A review of the potential effect of electroacupuncture and moxibustion on cell repair and survival: The role of heat shock proteins. Acupunct Med 27(4): 183-186.

17. Hong J, Wu G, Zou Y, Tao J, Chen L (2013) Electroacupuncture promotes neurological functional recovery via the retinoic acid signaling pathway in rats following cerebral ischemia-reperfusion injury. International Int J Mol Med 31(1): 225-231.

18. Li LX, Tian G, Meng ZH, Fan XN, Zhang CH, et al. (2014) Different stimulation intensities of acupuncture at Hegu (LI 4) for central facial nerve paralysis after ischemic stroke: a randomized controlled trial. Zhongguo Zhen Jiu 34(7): 669-674.

19.Zhou ZL, Li CX, Jiang YB, Zuo C, Cai Y, et al. (2012) Correlation between facial nerve functional evaluation and efficacy evaluation of acupuncture treatment for Bell's palsy. Zhong Xi Yi Jie He Xue Bao 10(9): 997-1002.

20. Zhou CD, Feng SW (2008) Effect of acupuncture at three acupoints of eye on Bell palsy. Zhongguo Zhen Jiu 28(7): 489-491. 


\section{Your next submission with Juniper Publishers will reach you the below assets}

- Quality Editorial service

- Swift Peer Review

- Reprints availability

- E-prints Service

- Manuscript Podcast for convenient understanding

- Global attainment for your research

- Manuscript accessibility in different formats ( Pdf, E-pub, Full Text, Audio)

- Unceasing customer service

Track the below URL for one-step submission https://juniperpublishers.com/online-submission.php 